\title{
Analiza procesów zachodzących podczas utleniania estrów metylowych wyższych kwasów tłuszczowych (FAME) oraz oleju napędowego B10 na podstawie danych literaturowych
}

\author{
Analysis of processes occurring during the oxidation of methyl esters of higher fatty acids \\ (FAME) and B10 diesel oil based on literature data
}

\author{
Winicjusz Stanik, Tomasz Łaczek \\ Instytut Nafty i Gazu - Państwowy Instytut Badawczy
}

\begin{abstract}
STRESZCZENIE: W artykule zebrano i przedstawiono informacje oraz dane literaturowe, które były podstawą przeprowadzenia analizy procesów i mechanizmów reakcji utleniania estrów metylowych kwasów tłuszczowych (FAME) oraz oleju napędowego B10 podczas długotrwałego przechowywania. Estry metylowe wyższych kwasów tłuszczowych (FAME) są mieszaniną mononienasyconych i wielonienasyconych cząsteczek FAME. Na podstawie uzyskanych danych wykazano, że cząsteczki wielonienasycone są bardziej podatne na utlenianie, a grupy metylenowe $\left(-\mathrm{CH}_{2}-\right)$ przylegające do nienasyconych atomów węgla w łańcuchu kwasu tłuszczowego są miejscem ataku i rozpoczęcia procesu utleniania. Zebrane informacje oraz analiza potwierdziły, że im więcej jest wiązań nienasyconych w łańcuchu kwasu thuszczowego, tym większa podatność FAME na atak tlenu i niestabilność oksydacyjną. W artykule przedstawiono i opisano schemat mechanizmów utleniania wielonienasyconych estrów kwasów tłuszczowych (FAME) oraz drugi zintegrowany proces utleniania estrów wyższych kwasów tłuszczowych (FAME) z konkurencyjnymi, alternatywnymi reakcjami utleniania. Odporność na utlenianie oleju napędowego B10 jest w dużym stopniu uzależniona od odporności na utlenianie estrów kwasów tłuszczowych (FAME). Na stabilność oksydacyjną oleju napędowego B10 oraz jego skłonność do tworzenia złożonych produktów utleniania ma również wpływ jakość samego oleju napędowego oraz reaktywność jego grup, które oddziałują na tworzenie złożonych produktów utleniania. Opierając się na danych literaturowych, stwierdzono, że do najbardziej reaktywnych grup odpowiedzialnych za powstawanie osadów nierozpuszczalnych w paliwie należą: węglowodory z wiązaniami nienasyconymi, organiczne związki azotu i siarki oraz organiczne związki zawierające tlen. Oprócz czynników wynikających z budowy cząsteczki estrów wyższych kwasów tłuszczowych FAME, jak i paliwa B10 w procesie utleniania istotną rolę odgrywają śladowe ilości jonów metali. Potwierdzono, że występowanie jonów metali powoduje przyśpieszenie procesu wolnorodnikowego utleniania. W obu omawianych przypadkach, czyli estrów kwasów tłuszczowych (FAME), jak i paliwa typu B10, oprócz omówionych czynników na proces utleniania mają jeszcze wpływ warunki przechowywania, a szczególnie: rodzaj i stężenie inhibitorów utleniania, temperatura przechowywania, ekspozycja światła i dostępność tlenu. W końcowej części artykułu krótko opisano wpływ inhibitorów utleniania na starzenie się oleju napędowego zawierającego FAME podczas przechowywania.
\end{abstract}

Słowa kluczowe: stabilność oksydacyjna, biopaliwa, estry metylowe wyższych kwasów tłuszczowych (FAME), inhibitory utleniania.

ABSTRACT: The article presents information and literature data that were the basis for the analysis of processes and mechanisms of the reaction of oxidation of fatty acid methyl esters (FAME) and B10 diesel oil during long-term storage. Methyl esters of higher fatty acids (FAME) are a mixture of monounsaturated and polyunsaturated FAME molecules. Based on the obtained data, it was shown that polyunsaturated molecules are more susceptible to oxidation, and methylene groups $\left(-\mathrm{CH}_{2}-\right)$, adjacent to unsaturated carbon atoms in the chain fatty acids are the site of attack and the beginning of the oxidation process. The collected information confirmed that the more unsaturated bonds in the fatty acid chain, the more FAME is prone to oxygen attack and oxidative instability. In addition to the factors resulting from the structure of the higher fatty acid esters molecule FAME and B10 fuel, trace amounts of metal ions play an important role in the oxidation process. It has been confirmed that the presence of metal ions accelerates the oxidation process. The article presents and describes the diagram of the mechanisms of oxidation of polyunsaturated fatty acid esters (FAME) and the second integrated oxidation process of higher fatty acid esters (FAME) with competitive alternative oxidation reactions. B10 diesel oxidation resistance is highly dependent on the oxidation resistance of fatty acid esters (FAME). The oxidative stability of B10 diesel fuel and its propensity to form complex oxidation products is also affected by the quality of diesel fuel itself and the reactivity of the groups that

Autor do korespondencji: T. Łaczek; e-mail: tomasz.laczek@inig.pl

Artykuł nadesłano do Redakcji: 06.04.2020 r. Zatwierdzono do druku: 17.09.2020 r. 
affect the formation of complex oxidation products. Based on the literature data, it was found that the most reactive groups responsible for the formation of fuel insoluble sediments include: hydrocarbons with unsaturated bonds, organic nitrogen and sulfur compounds and organic oxygen-containing compounds. In both discussed cases, i.e. fatty acid esters (FAME) and B10 fuels, in addition to the factors discussed above, the oxidation process is also affected by storage conditions, in particular the concentration of oxidation inhibitors, storage temperature and light exposure and oxygen availability. The final part of the article discusses the effect of oxidation inhibitors on the aging of diesel containing (FAME) during storage.

Key words: oxidative stability, biofuels, higher fatty acid methyl esters (FAME), oxidation inhibitors.

\section{Wstęp}

Aby poradzić sobie ze zwiększonym zapotrzebowaniem na energię, od wielu lat prowadzone są szerokie badania w dziedzinie paliw alternatywnych, a w szczególności nad biodieslem, który jest dobrym zamiennikiem oleju napędowego pochodzenia naftowego (Sacha, 2019). Mieszanie i stosowanie oleju napędowego pochodzenia naftowego z FAME ma na celu z jednej strony zwiększenie ilości dostępnego paliwa na ryn$\mathrm{ku}$, a z drugiej - zmniejszenie szkodliwości eksploatowanego paliwa dla środowiska naturalnego. Należy zaznaczyć, że cała zawartość węgla organicznego w FAME pochodzi z fotosyntezy dwutlenku węgla oraz wody i nie przyczynia się do wzrostu poziomu $\mathrm{CO}_{2} \mathrm{w}$ atmosferze, a także nie powoduje tzw. efektu cieplarnianego. Zastosowanie w „blendingu” estrów wyższych kwasów tłuszczowych wiąże się jednak z obniżeniem jakości powstałego oleju napędowego. Głównym parametrem, który ulega pogorszeniu, jest stabilność oksydacyjna, czyli odporność paliwa na utlenianie. Niekorzystne zmiany stabilności oksydacyjnej paliw mieszanych, jak np. paliwa B10, są widoczne w łańcuchu dystrybucji już na etapie przewożenia i magazynowania paliwa oraz podczas eksploatacji silnika. Proces utleniania paliwa prowadzi do tworzenia się w nim różnego rodzaju osadów, żywic i kwasów. Utlenione paliwo może powodować zatykanie instalacji magazynowej, a w skrajnych przypadkach zniszczenie i utratę całej partii zgromadzonego paliwa. Powstałe produkty utleniania mogą uszkadzać pompy paliwowe, blokować filtry i przewody paliwowe. Osadzając się na końcówkach wtryskiwaczy, zaburzają one proces wtrysku paliwa. Kwaśne produkty utleniania przyczyniają się do degradowania elementów silnika, powodując zwiększoną korozję oraz szybkie niszczenie różnego rodzaju uszczelnień (Sacha, 2013). Dlatego tak istotne stało się rozeznanie tego zagadnienia.

\section{Stan wiedzy}

Utlenianie oleju napędowego B10 z udziałem estrów metylowych kwasów tłuszczowych (FAME) podczas magazynowania to złożony, wieloetapowy proces reakcji chemicznych, który rozpoczyna się od powstawania nadtlenków i wodoronadtlenków jako pierwotnych produktów utleniania. Pierwotne produkty utleniania uczestniczą następnie w mechanizmie powstawania wtórnych produktów utleniania w postaci aldehydów, niskocząsteczkowych kwasów karboksylowych, kwasu mrówkowego, estru kwasu mrówkowego i wysokocząsteczkowych oligomerów kwasów thuszczowych utworzonych w wyniku polimeryzacji utleniającej. Produkty powstałe z wtórnego procesu utleniania tworzą żywice, szlamy i inne nierozpuszczalne w paliwie związki blokujące filtry paliwowe. Stabilność estrów metylowych kwasów tłuszczowych jest silnie zależna od składu komponentowego FAME, a w szczególności od ilości nienasyconych estrów kwasów thuszczowych znajdujących się w biopaliwie. Estry metylowe kwasów tłuszczowych (FAME) to mieszanina mononienasyconych kwasów tłuszczowych (monounsaturated fatty acids - MUFA), zawierających jedno nienasycone podwójne wiązanie $-\mathrm{C}=\mathrm{C}-$, oraz wielonienasyconych kwasów thuszczowych (polyunsaturated fatty acids - PUFA) zawierających więcej niż jedno nienasycone podwójne wiązanie oddzielone grupą metylenową $-\mathrm{CH}_{2}-$. Wielonienasycone estry kwasów tłuszczowych są znacznie bardziej podatne na utlenianie niż estry mononienasycone, ponieważ ich łańcuchy zawierają większą liczbę miejsc reaktywnych (Knothe i Dunn, 2003). Pozycja bis-allilowa $\left(-\mathrm{CH}=\mathrm{CH}-\mathrm{CH}_{2}-\mathrm{CH}=\mathrm{CH}-\right)$ to dwa wiązania podwójne w konfiguracji cis rozdzielone pojedynczą grupą metylenową $\left(-\mathrm{CH}_{2}-\right)$. Grupy metylenowe $\left(-\mathrm{CH}_{2}-\right)$ przylegające do nienasyconych atomów węgla w łańcuchu kwasu tłuszczowego są głównym miejscem ataku tlenu rozpuszczonego w FAME. Im więcej występuje wiązań nienasyconych w łańcuchu kwasu tłuszczowego, tym bardziej FAME jest podatne na atak tlenu i niestabilność oksydacyjną (Ramos et al., 2009). Przewidywanie stabilności oksydacyjnej olejów napędowych z podwyższoną zawartością FAME i oszacowanie okresu przechowywania takiego paliwa jest jeszcze niemożliwe.

W literaturze znanych jest wiele wskaźników opartych na profilach składu frakcyjnego estrów metylowych kwasów thuszczowych:

- Wartość jodowa (iodine value) lub liczba jodowa (iodine number) określająca stężenie wiązań podwójnych. Limit wartości liczby jodowej dla estrów metylowych kwasów thuszczowych według normy PN-EN 14214 + A1:2014 Estry metylowe kwasów tluszczowych (FAME) do użytku 
$w$ silnikach samochodowych o zaptonie samoczynnym (Diesla) i zastosowań grzewczych. Wymagania i metody badań (PN-EN 14214 + A1:2014) wynosi maksymalnie $120 \mathrm{~g}$ jodu/100 g.

- Alternatywnie Knothe zaproponował jako wskaźniki stabilności biodiesla APE i BAPE, które umożliwiają obliczenie względnej skłonności do utleniania estrów metylowych kwasów tłuszczowych o różnym profilu zawartości nienasyconych kwasów tłuszczowych (Knothe, 2002). Jako kryteria różnej reaktywności pozycji allilowych i bi$\mathrm{s}$-allilowych, indeksy te nazwał allylic position equivalent (APE) i bis-allylic position equivalent (BAPE). Ponieważ każdy kwas thuszczowy nienasycony zawiera dwie pozycje allilowe, dlatego APE oblicza się według równania (1):

$$
\mathrm{APE}=2 \times\left(\mathrm{Ac}_{18: 1}+\mathrm{Ac}_{18: 2}+\mathrm{Ac}_{18: 3)}\right.
$$

gdzie Ac oznacza stężenie w procentach masowych odpowiednich związków $\mathrm{C}_{18}$.

Na przykład kwas linolenowy zawiera jedną pozycję bis-allilową, dlatego BAPE oblicza się według wzoru (2):

$$
\mathrm{BAPE}=\left(\mathrm{Ac}_{18: 2}+2 \mathrm{Ac}_{18: 3}\right)
$$

McCormick i inni wykazali, że indeks stabilności oksydacyjnej $O X$ przedstawiony wzorem (3):

$$
O X=\frac{0,02\left[\left(\% A c_{18: 1}\right)+\left(\% A c_{18: 2}\right)+2\left(\% A c_{18: 3}\right)\right]}{100}
$$

gdzie:

$\mathrm{Ac}_{\text {18:1 }}$ - oznacza zawartość procentową kwasu oleinowego (18:1),

$\mathrm{Ac}_{18: 2}$ - oznacza zawartość procentową kwasu linolowego (18:2),

$\mathrm{Ac}_{18: 3}$ - oznacza zawartość procentową kwasu linolowego (18:3),

może służyć do obliczenia stabilności oksydacyjnej estrów metylowych kwasów tłuszczowych (McCormick et al., 2007).

Rodniki nadtlenkowe powstałe w wyniku reakcji z tlenem oderwanego wodoru bis-allilowego innych wielonienasyconych estrów kwasów tłuszczowych tworzą wodoronadtlenki i dodatkowe rodniki estrowe, które zapoczątkowują rozwój reakcji łańcuchowej, tworząc nadtlenkowe dimery estrowe.

Powstałe wodoronadtlenki są stosunkowo niestabilne i reagują wewnątrzcząsteczkowo, rozczepiając przylegający do wiązania podwójnego w rodniku związek o różnej masie cząsteczkowej, który następnie tworzy kwasy, aldehydy, ketony, alkohole, olefiny i alkany (Eldin, 2003; Catala, 2012; Chuck et al., 2012).

Te reaktywne związki przejściowe ulegają dalszym reakcjom, tworząc produkty oligomeryczne i polimeryczne (Chuck et al., 2012).
Rozkład wodoronadtlenków katalizowany jest już przy niewielkiej ilości jonów metali takich jak $\mathrm{Fe}, \mathrm{Cu}, \mathrm{Ni}, \mathrm{Mn}, \mathrm{Co}$ (Jain i Sharma, 2012).

Na rysunku 1 przedstawiono produkty wtórnego rozkładu wodoronadtlenków, a na rysunku 2 - mechanizm utleniania wielonienasyconych estrów kwasów tłuszczowych, który obejmuje trzy fazy (Eldin, 2003; Christensen i McCormick, 2014).

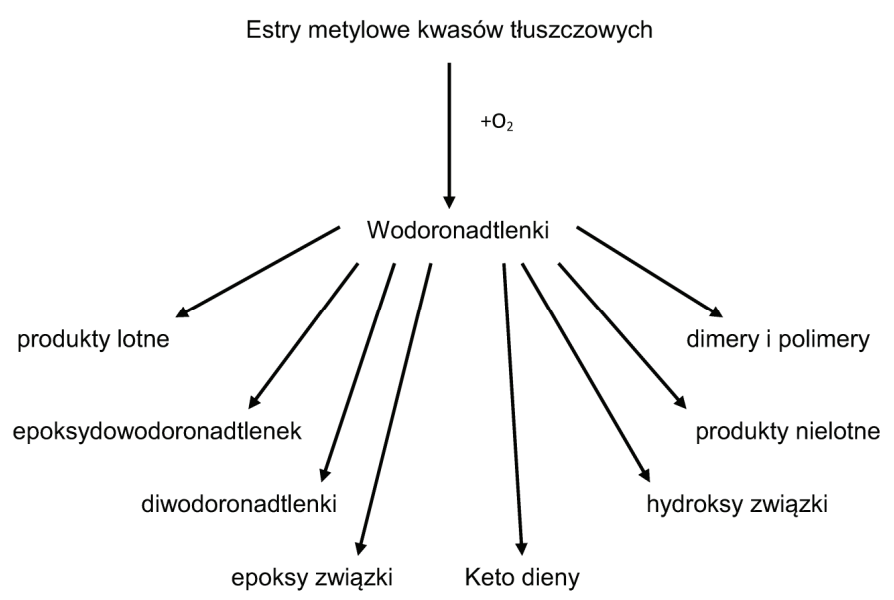

Rys. 1. Produkty wtórnego rozkładu wodoronadtlenków (Eldin, 2003; Christensen i McCormick, 2014)

Fig. 1. Products of secondary decomposition of hydroperoxides (Eldin, 2003; Christensen and McCormick, 2014)

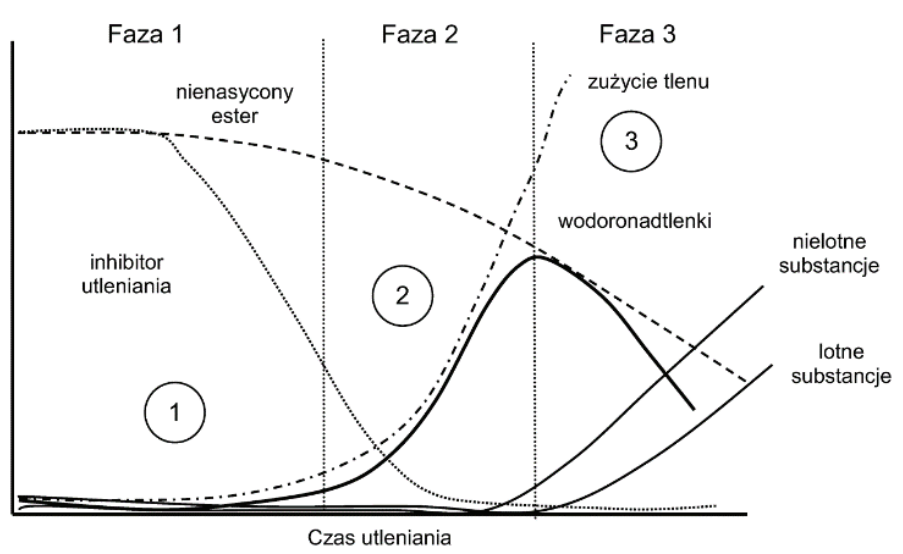

Rys. 2. Kinetyczne krzywe utleniania wielonienasyconych kwasów thuszczowych (Eldin, 2003; Christensen i McCormick, 2014)

Fig. 2. Kinetic oxidation curves of polyunsaturated fatty acids (Eldin, 2003; Christensen and McCormick, 2014)

Faza pierwsza to okres indukcyjny, w którym zużycie tlenu postępuje powoli w wyniku działania inhibitorów utleniania. W miarę upływu czasu następuje spadek stężenia inhibitorów utleniania, lecz jakość estrów metylowych kwasów tłuszczowych nie ulega degradacji utleniającej, ponieważ tworzące się wolne rodniki reagują głównie z inhibitorami utleniania.

Czas, w jakim paliwo pozostaje w tej fazie procesu utleniania, zależy od reaktywności estrów oraz stężenia i rodzaju 
zastosowanych inhibitorów utleniania, a także wpływu temperatury, ekspozycji światła i dostępności tlenu.

Druga faza procesu utleniania to faza wykładniczego wzrostu wodoronadtlenków i zużycie tlenu oraz całkowity spadek stężenia inhibitorów utleniania.

W trzeciej fazie procesu utleniania paliwa szybkość rozkładu wodoronadtlenków jest wyższa od szybkości ich generowania, w związku z czym następuje gwałtowny wzrost produkcji lotnych kwasów i aldehydów oraz produktów ich wtórnych reakcji, tworzących produkty będące prekursorami osadów.

Przewidywanie stabilności oksydacyjnej paliwa i czasu indukcji utleniania podczas przechowywania paliwa jest złożonym procesem wielu reakcji chemicznych zależnych od temperatury, reaktywności estrów metylowych kwasów tłuszczowych z tlenem, obecności śladowych ilości metali katalizujących rozkład wodoronadtlenków, doboru odpowiednich inhibitorów utleniania.

Zintegrowany mechanizm utleniania estrów metylowych kwasów tłuszczowych ukazujący konkurencyjne reakcje alternatywne przedstawiono na rysunku 3 (Schaich, 2005; Schaich et al., 2017).

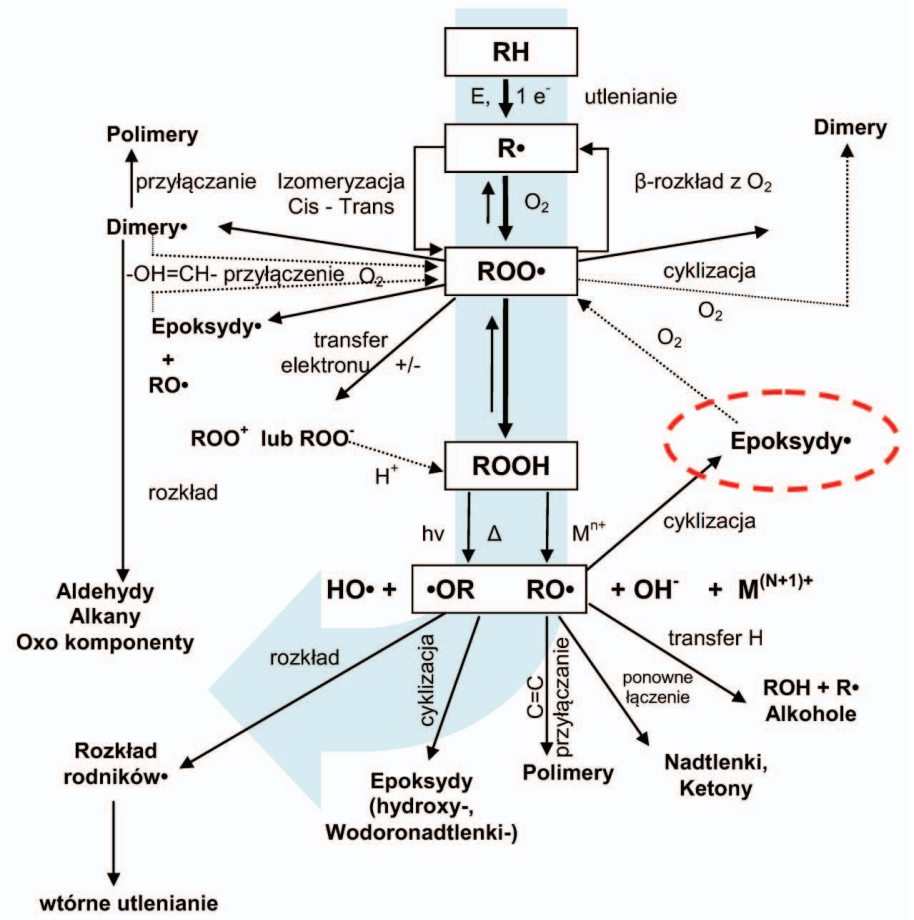

Rys. 3. Zintegrowany schemat utleniania estrów metylowych kwasów tłuszczowych (Schaich, 2005; Schaich et al., 2017)

Fig. 3. Integrated scheme for the oxidation of fatty acid methyl esters (Schaich, 2005; Schaich et al., 2017)

Niebieska strzałka oznacza klasyczną reakcję łańcuchową napędzaną przeniesieniem wolnego rodnika wodoru pobranego z wiązania metylenowego.
Przerywane linie wskazują ścieżki przyłączenia tlenu do wtórnych wolnych rodników z utworzeniem produktów cyklicznych lub do wiązań nienasyconych z utworzeniem nowych rodników nadtlenkowych.

Wszystkie reakcje alternatywne konkurują ze sobą, a równowaga między nimi zmienia się wraz z warunkami termicznymi i dostępnością tlenu.

Śladowe ilości metali pochodzące z produkcji biodiesla oraz z procesów rafineryjnych mają kluczowy wpływ na jakość i stabilność oleju napędowego z udziałem FAME (Sarin et al., 2009). Obecność metali w estrach metylowych kwasów tłuszczowych powoduje przyspieszenie wolnorodnikowego utleniania. W wyniku inicjacji reakcji łańcuchowej następuje rozkład wodoronadtlenków według reakcji I, II (Jain i Sharma, 2014):

$$
\begin{aligned}
& \mathrm{ROOH}+\mathrm{M}^{2+}=\mathrm{RO} \cdot+\mathrm{OH}+\mathrm{M}^{3+} \\
& \mathrm{ROOH}+\mathrm{M}^{3+}=\mathrm{ROO} \cdot+\mathrm{H}^{+}+\mathrm{M}^{2+}
\end{aligned}
$$

Miedź ma najsilniejsze działanie katalityczne, a inne metale - żelazo, nikiel, mangan i kobalt również negatywnie wpływają na stabilność utleniana, co przedstawiono na rysunku 4.

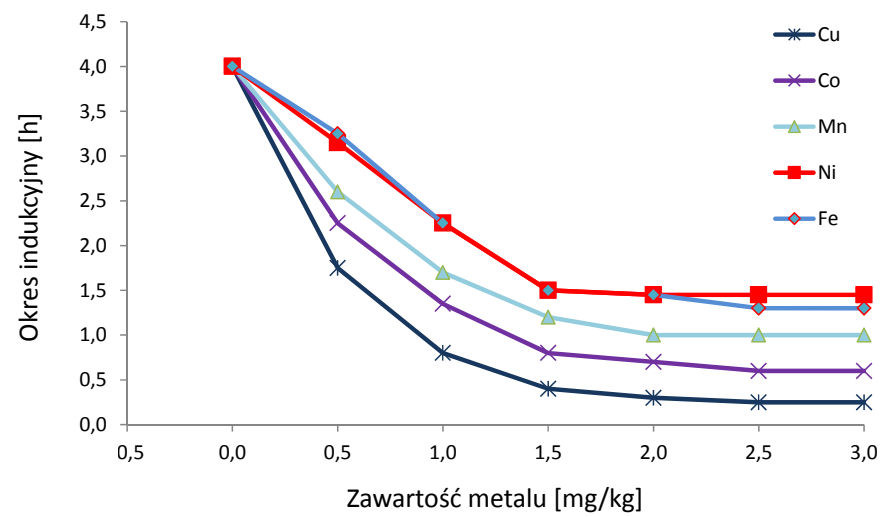

Rys. 4. Wpływ metali na stabilność oksydacyjną (Jain i Sharma, 2014)

Fig. 4. The effect of metals on oxidative stability (Jain and Sharma, 2014)

Wpływ katalityczny metali na utlenianie estrów metylowych kwasów tłuszczowych od najsilniejszego do najsłabszego jest następujący (Knothe i Steidley, 2018):

$$
\mathrm{Cu}>\mathrm{Co}>\mathrm{Mn}>\mathrm{Ni}>\mathrm{Fe}
$$

Mieszanie (blendowanie) oleju napędowego pochodzenia naftowego z FAME zależy również od jakości oleju napędowego pochodzenia naftowego zawierającego reaktywne grupy wpływające na stabilność oksydacyjną oleju oraz tworzenie złożonych produktów utleniania.

Do reaktywnych grup wpływających na tworzenie osadów nierozpuszczalnych $\mathrm{w}$ paliwie należą: węglowodory z wiązaniami nienasyconymi, organiczne związki azotu i siarki, 


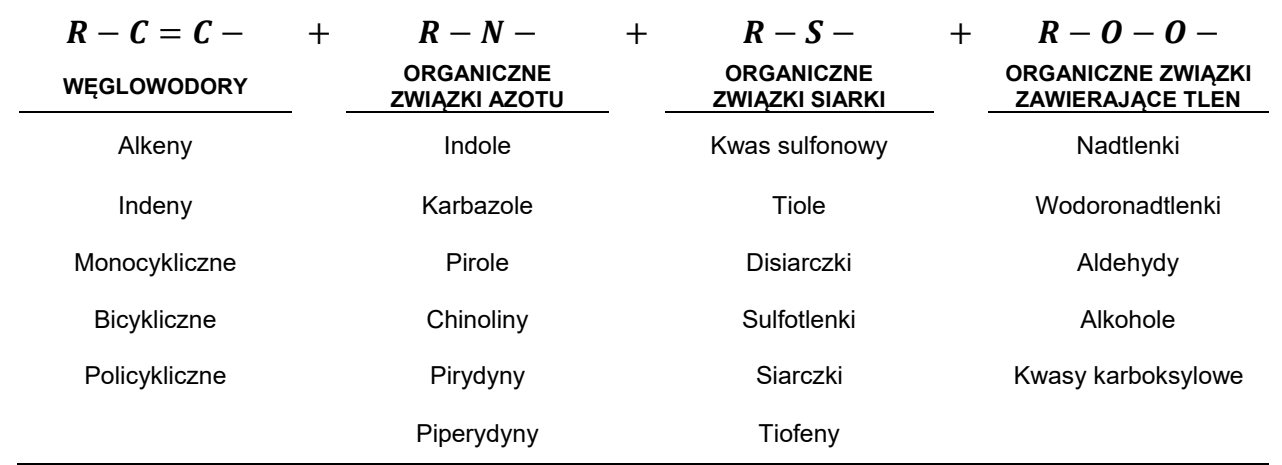

Rys. 5. Grupy wpływające na tworzenie złożonych produktów utleniania

Fig. 5. Groups affecting the formation of complex oxidation products

organiczne związki zawierające tlen. Na rysunku 5 przedstawiono reaktywne grupy wpływające na powstanie złożonych produktów utleniania tworzących osady nierozpuszczalne (Pedley et al., 1988, 1989).

Reaktywne związki z grupami funkcyjnymi przedstawionymi na rysunku 5 są potencjalnym źródłem wielu reakcji chemicznych z wodoronadtlenkami, które inicjują polimeryzację związków nienasyconych i tworzą żywice. Transfer elektronu do reaktywnych grup funkcyjnych z wolnych rodników powoduje inicjowanie procesów utleniania. Wodoronadtlenki utleniają związki siarkoorganiczne do kwasów sulfonowych, które następnie katalizują reakcje kondensacji, między innymi z grupami funkcyjnymi zawierającymi azot, tworząc wielkocząsteczkowe rozpuszczalne w paliwie oksydacyjnie reaktywne formy SMORS (soluble macromolecular oxidatively reactive species).

Ileri i Kocar badali wpływ różnych inhibitorów utleniania i azotanu 2-etyloheksylu na stabilność oksydacyjną oleju napędowego B20 (Ileri i Kocar, 2014).

Stabilność oleju napędowego B20 bez inhibitorów utleniania według metody PN-EN 15751 Paliwa do pojazdów samochodowych - Estry metylowe kwasów thuszczowych (FAME) jako samoistne paliwo $i$ ich mieszaniny z olejem napedowym - Oznaczanie stabilności oksydacyjnej metoda przyspieszonego utleniania $\left(\right.$ Rancimat $^{\circledR}$ ) wynosiła $6,9 \mathrm{~h}$.

Jak pokazano na rysunku 6 , stabilność oksydacyjna była najwyższa w przypadku TBHQ (tert-butylohydrochinonu) przy stężeniu $1000 \mathrm{mg} / \mathrm{kg}$ i wynosiła 38,7 h. Dodatek $1000 \mathrm{mg} / \mathrm{kg}$ azotanu 2-etyloheksylu podnosił stabilność oksydacyjną oleju napędowego B20 z 6,9 h do 9,8 h. Zgodnie z uzyskanymi wynikami badań stabilność oksydacyjna wykazała skuteczność inhibitorów utleniania w następującej kolejności (Ileri i Kocar, 2014):

TBHQ (tert-butylohydrochinon) > BHA (tert-butylowany hydroksyamisol) $>$ BHT (tert-butylowany hydroksytoluen) $>$ 2-EHN (azotan 2-etyloheksylu)

Skuteczność przeciwutleniająca badanych inhibitorów utleniania zależy od liczby aktywnych grup hydroksylowych $(-\mathrm{OH})$ w strukturze molekularnej inhibitora. Poprzez oderwanie wodoru z grupy hydroksylowej inhibitora utleniania tworzy się stabilny, niereaktywny w procesie utleniania wolny rodnik, który jest stabilizowany przez przestrzenie grup tert-butylowych oraz interakcję rezonansową z pierścieniami aromatycznymi. Tert-butylohydrochinon (TBHQ) zawiera dwie grupy hydroksylowe, dlatego jego skuteczność inhibitująca jest wyższa niż inhibitorów zawierających jedną grupę hydroksylową.

Również badania stabilności oksydacyjnej oznaczonej metodą PN-EN 15751 (PN-EN 15751) dla oleju napędowego zawierającego powyżej 2 procent FAME i z zawartością azotanu

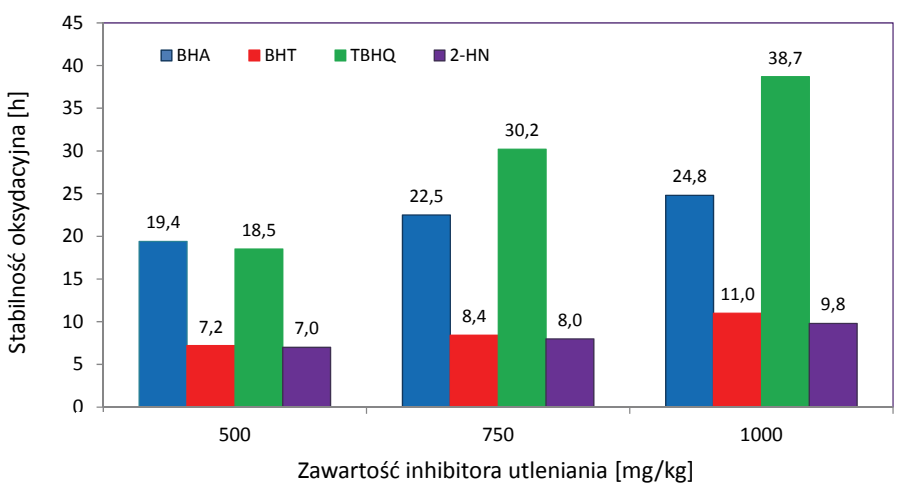

Rys. 6. Wpływ stężeń inhibitorów utleniania na stabilność oksydacyjną oleju napędowego B20 (Ileri i Kocar, 2014)

Fig. 6. Impact of oxidation inhibitor concentrations on the oxidative stability of B20 diesel fuel (Ileri and Kocar, 2014)

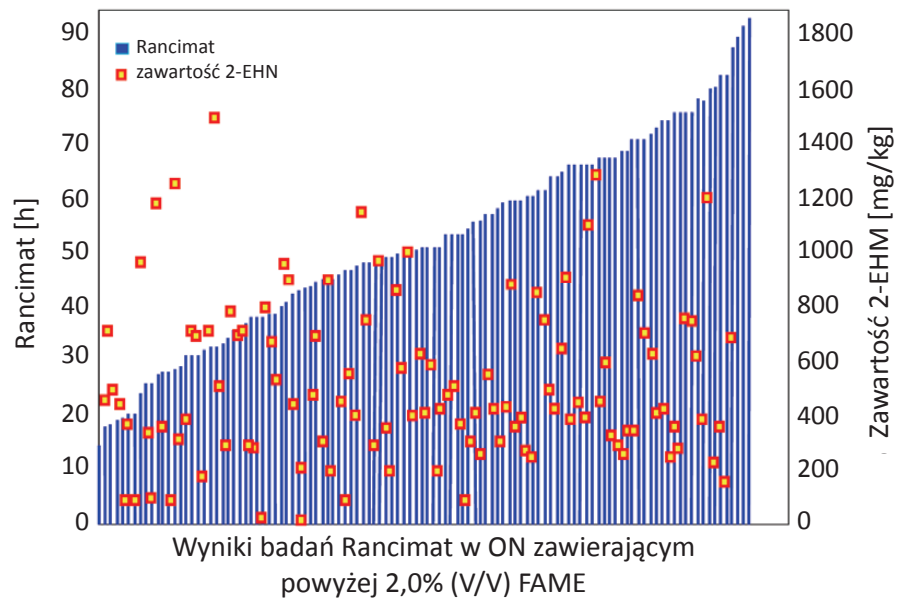

Rys. 7. Wpływ zawartości azotanu 2-eytloheksylu w oleju napędowym zawierającym powyżej 2\% (V/V) FAME na stabilność oksydacyjną oznaczoną metodą EN 1575 (EN 15751)

Fig. 7. Impact of 2-eytlohexyl nitrate content in diesel fuel containing more than $2 \%(V / V)$ FAME on oxidative stability determined by the method EN 1575 (EN 15751) 
2-etyloheksylu w ilości $200 \mathrm{mg} / \mathrm{kg}$ do $1800 \mathrm{mg} / \mathrm{kg}$ przeprowadzone i opublikowane w Fuel Survey przez CONCAWE wykazały wpływ azotanu 2-etyloheksylu na stabilność oksydacyjną, co przedstawiono na rysunku 7 (Rose, 2011).

Wpływ azotanu 2-etyloheksylu na olej napędowy zawierający FAME w ilości 5\% $(V / V)$ do 20\% $(V / V)$ jest przedmiotem dalszych badań.

\section{Podsumowanie}

Przeprowadzenie przeglądu literaturowego na temat procesów i mechanizmów utleniania było podyktowane koniecznością rozeznania stanu wiedzy i możliwości realizacji w INiG - PIB zleconej pracy badawczej. Przedstawione w artykule dane literaturowe oraz ich analiza pozwoliły na wskazanie zależności reakcji zachodzących podczas utleniania estrów metylowych wyższych kwasów tłuszczowych (FAME) oraz oleju napędowego B10.

W artykule zaprezentowano schemat przebiegu utleniania wielonienasyconych estrów kwasów thuszczowych (FAME). Na podstawie trójfazowego mechanizmu reakcji utleniania estrów wyższych kwasów tłuszczowych (FAME) i oceny zachodzących procesów wskazano miejsca inicjacji reakcji utleniania w poszczególnych fazach starzenia się estrów wyższych kwasów tłuszczowych (FAME). Źródła literaturowe podają, że istnieje inny zintegrowany konkurencyjny mechanizm utleniania estrów metylowych wyższych kwasów tłuszczowych (FAME), ukazujący dodatkowe alternatywne reakcje utleniania. W obu przypadkach na schematach wskazano miejsca ataku tlenu i jego destruktywne działanie na stabilność oksydacyjną estrów metylowych. Opisano również pośrednie produkty powstające w poszczególnych fazach procesu i ich bezpośrednie oddziaływanie na kolejne cykle procesu utleniana.

Stwierdzono, że odporność na utlenianie olejów napędowych zawierających FAME jest w dużej mierze uzależniona od odporności na utlenianie użytych w „blendingu” estrów wyższych kwasów tłuszczowych (FAME). Stabilność olejów napędowych zawierających FAME oraz tworzenie złożonych produktów utleniania zależy również od jakości stosowanego oleju napędowego pochodzenia naftowego oraz reaktywnych grup występujących w strukturze paliwa, takich jak węglowodory z wiązaniami nienasyconymi, organiczne związki azotu i siarki, organiczne związki zawierające tlen. Dodatkowymi czynnikami, które decydują o przebiegu złożonych reakcji utleniania, są: tlen, oddziaływanie światła na paliwo, temperatura i czas przechowywania, rodzaj i zawartość inhibitorów oraz obecność jonów metali.

$\mathrm{Na}$ podstawie zebranych danych literaturowych dodatkowo pokazano, że proces pogarszania stabilności oksydacyjnej paliwa można znacząco spowolnić, stosując dodatki uszlachetniające zwane inhibitorami utleniania. Przykład wpływu różnych inhibitorów na stabilność oksydacyjną został przedstawiony w tym artykule. W zależności od zastosowanego inhibitora utleniania uzyskano wzrost odporności na utlenianie paliwa w stosunku do paliwa bazowego (ocena na aparacie Rancimat ${ }^{\mathbb{R}}$ ).

Artykuł powstał na podstawie pracy badawczej pt. Zaawansowany technologicznie dodatek do oleju napędowego dla maszyn pozadrogowych ze szczególnym uwzględnieniem maszyn górnictwa podziemnego o znaczaco ulepszonych właściwościach energetycznych i emisyjnych. RAPORT 6 Badania czasu przechowywania B10 uszlachetnionego modyfikatorem procesu spalania - nr zlecenia: 0429/TM/2018, nr archiwalny: DK-4100-154/2018.

\section{Literatura}

Catala A., 2012. Lipid peroxidation. In-Tech, Croatia.

Christensen E., McCormick R.Z., 2014. Long-term storage stability of biodiesel and biodiesel blends. Fuel Processing Technology, 128: 339-348.

Chuck Ch.J., Jenkins R.W., Bannistern Ch.D., Han L., Lowe J.P., 2012. Design and preliminary results of an NMR tube reactor to study the oxidation degradation of fatty acid methyl ester. Biomass and Bioenergy, 47: 188-194.

Eldin A.K., 2003. Lipid oxidation pathways. AOCS Press, Illinois.

Ileri E., Kocar G., 2014. Experimental investigation of the effect of antioxidant additives on $\mathrm{NO}_{\mathrm{x}}$ emissions of Diesel engine using biodiesel. Fuel, 125: 444-449.

Jain S., Sharma M.P., 2012. Correlation development between the oxidation and thermal stability of biodiesel. Fuel, 102: 354-358.

Jain S., Sharma M.P., 2014. Effect of metal contents on oxidation stability of biodiesel - diesel blends. Fuel, 116: 14-18.

Knothe G., 2002. Structure indices in FA Chemistry. How Relevant is the Iodine Value? Journal of the American Oil Chemists Society, 79: 823-833.

Knothe G., Dunn R.O., 2003. Dependence of oil stability index of fatty compounds on their structure and concentration and presence of metals. Journal of the American Oil Chemists'Society, 80(10): 1021-1026.

Knothe G., Steidley K.R., 2018. The effect of metals and metal oxides on biodiesel oxidative stability from promotion to inhibition. Fuel Processing Technology, 177: 75-80.

McCormick R.L., Ratcliff M., Morns L., Lawrence R., 2007. Several factors affecting the stability of biodiesel in standard accelerated tests. Fuel Processing Technology, 88: 651-665.

Pedley J., Hiley W., Hancock R.A., 1988. Storage stability of petroleum-derived diesel fuel: 3 . Identification of compounds involved in sediment formation. Fuel, 67(8): 1124-1130.

Pedley J., Hiley W., Hancock R.A., 1989. Storage stability of petroleum-derived diesel fuel: 4. Synthesis of sediment precursor compounds and simulation of sediment formation using model systems. Fuel, 68(1): 27-31.

Ramos M.J., Fernández C.M., Casas A., Rodríguez L., Pérez A., 2009. Influence of fatty acid composition of raw materials on biodiesel properties. Bioresource Technology, 100: 261-268.

Rose K.D., 2011. Fuels and Emissions Research Activities. JPEC/ CONCAWE Information Exchange Meeting, 31st August, 2011.

Sacha D., 2013. Ocena stabilności oksydacyjnej paliw do silników o zapłonie samoczynnym według projektowanych wymagań CEN. Nafta-Gaz, 11: 858-867. 
Sacha D., 2019. Wpływ metali nieżelaznych na stabilność oksydacyjną paliw do silników o zapłonie samoczynnym. Nafta-Gaz, 9: 579-586. DOI: 10.18668/NG.2019.09.07.

Sarin A., Arora R., Singh N.P., Sharma M., Malhotra R.K., 2009. Influence of metal contaminants on oxidation stability of Jatropha Biodiesel. Energy, 34(9): 1271-1275.

Schaich K.M., 2005. Lipid Oxidation: Theoretical Aspects. [W:] Shahidi F. (ed.). Bailey's Industrial Fat and Oil Products. John Wiley, New York, 1: 269-355.

Schaich K.M, Xie J., Bogusz A., 2017. Thinking outside the classical chain reaction box of lipid oxidation. Evidence for alternate pathways and the importance of epoxides. Lipid Technology, 29(9-10): 91-96.

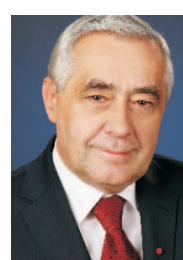

Dr Winicjusz STANIK

Adiunkt; kierownik Zakładu Produkcji

Doświadczalnej i Małotonażowej oraz Sprzedaży

Instytut Nafty i Gazu - Państwowy Instytut Badawczy

ul. Lubicz 25 A, 31-503 Kraków

E-mail: winicjusz.stanik@inig.pl

\section{Normy}

PN-EN $14214+$ A1:2014 Estry metylowe kwasów tłuszczowych (FAME) do użytku w silnikach samochodowych o zapłonie samoczynnym (Diesla) i zastosowań grzewczych. Wymagania i metody badań.

PN-EN 15751 Paliwa do pojazdów samochodowych - Estry metylowe kwasów tłuszczowych (FAME) jako samoistne paliwo i ich mieszaniny z olejem napędowym - Oznaczanie stabilności oksydacyjnej metodą przyspieszonego utleniania.

\section{OFERTA ZAKKADU PRODUKCJI DOŚWIADCZALNEJ I MAKOTONAŻOWEJ ORAZ SPRZEDAŻY}

- produkcja małotonażowa i sprzedaż specyfików naftowych w ilościach od 10 do 25000 kg/ szarżę:

» olejów i środków smarowych,

» zaawansowanych technologicznie specyfików dla wojska,

» preparatów myjących,

» inhibitorów korozii i rdzewienia,

» dodatków i pakietów dodatków uszlachetniających (dobieranie do paliw indywidualnie):

- do przerobu ropy naftowej (procesowe),

- do benzyn silnikowych,

- do paliw lotniczych,

- do olejów napędowych,

- do olejów opałowych,

- do paliw alternatywnych (biopaliw),

- biocydów do paliw naftowych i biopaliw,

» opracowywanie kart charakterystyki substancji i mieszanin niebezpiecznych, zgodnie z obowiązującymi przepisami praw.

Kierownik: dr Winicjusz Stanik Adres: ul. Łukasiewicza 1, 31-429 Kraków Telefon: 126177525 Faks: 126177522 E-mail:winicjusz.stanik@inig.pl

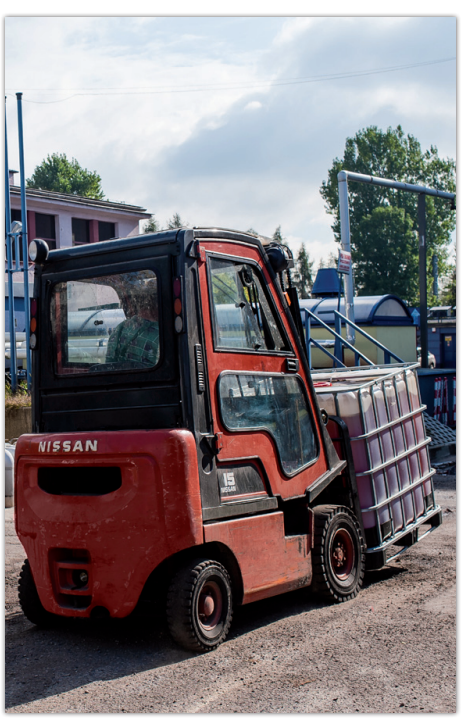

INSTYTUT NAFTY I GAZU - Państwowy Instytut Badawczy 